\title{
Hvorfor får man lettere bakterielle infeksjoner ved influensa?
}

\section{Nedsatt evne til å reparere vevsskade kan være én årsak til sekundære bakterielle infeksjoner ved influensainfeksjon.}

Sekundær bakteriell pneumoni fører til økt morbiditet og mortalitet ved influensavirusinfeksjoner. For å finne årsaken til den økte mottakeligheten for bakterielle infeksjoner ved pågående influensainfeksjon har amerikanske forskere brukt en musemodell hvor immuntoleranse og immunresistens kunne studeres hver for seg ved samtidig infeksjon med virus og bakterier (1).

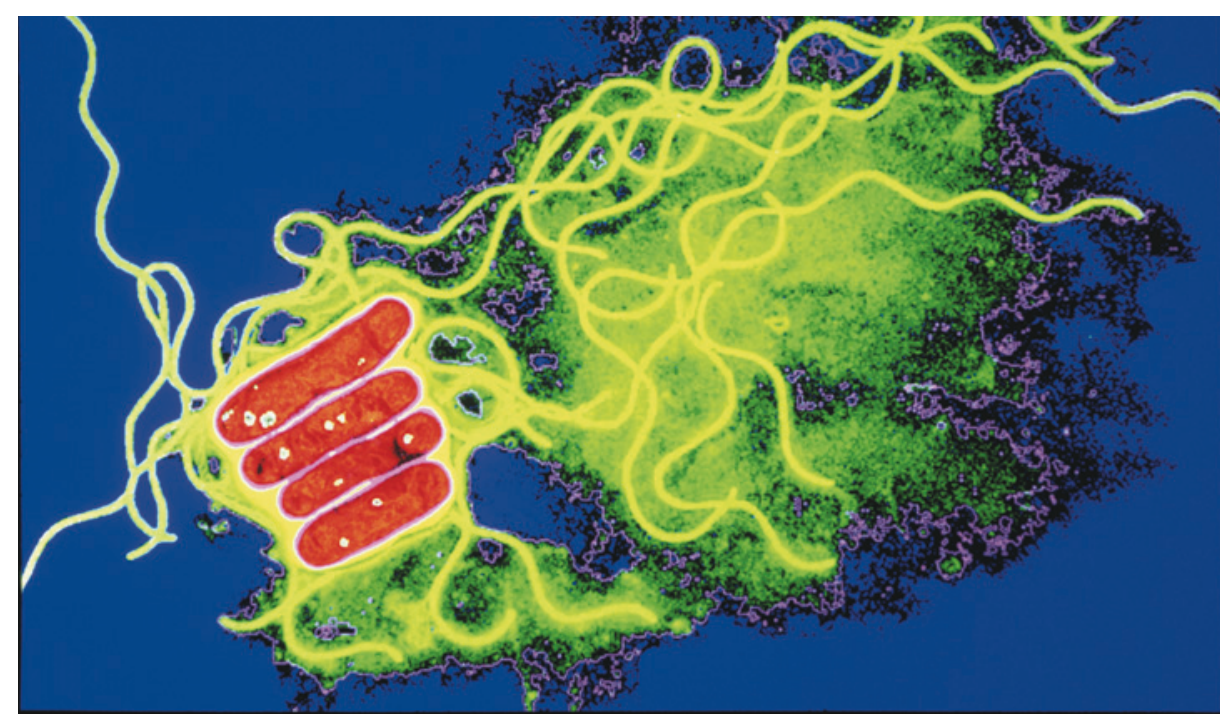

Illustrasjonsfoto Science Photo Library/NTB scanpix
Mus som ble infisert med influensavirus noen dager før de ble infisert med Legionella pneumophila, døde, mens de musene som kun ble infisert med én av disse mikrobene overlevde. En produktiv virusinfeksjon var nødvendig for å gjøre dyrene mottakelige for bakterieinfeksjon. Bakteriell virulens eller vekst var ikke vesentlig for den letale synergieffekten, og den skyldtes heller

ikke svekket immunrespons mot bakterien. Derimot hadde dyrene som var infisert med både influensavirus og L. pneumophia betydelig mer skade i lungeepitelet enn mus som var infisert med bare ett agens.

- Det er velkjent at influensainfeksjon i lungene kan disponere for bakterielle infeksjoner, bl.a. med pneumokokker og gule stafylokokker, på grunn av spesifikk nedsatt immunrespons mot disse bakteriene, sier professor Pål Aukrust ved Seksjon for klinisk immunologi og infeksjonsmedisin, Oslo universitetssykehus, Rikshospitalet. - Økt forekomst av symptomatiske infeksjoner kan også skyldes nedsatt evne til å «tolerere» mikrobene eller reparere skadene de utløser. Denne studien viser at dette kan være én mekanisme ved bakterielle infeksjoner ved influensainfeksjon, sier han.

- Det var ingen endret immunrespons eller økt mikrobemengde hos de musene som døde ved koinfeksjon. De hadde imidlertid betydelig nedsatt evne til å reparere vevsskade i lungene, bl.a. via nedregulering av en rekke mediatorer. Dette er en interessant mekanisme for utvikling av influensaassosierte koinfeksjoner, sier Aukrust.

\section{Trine B. Haugen}

trine.b.haugen@hioa.no

Tidsskriftet

\section{Litteratur}

1. Jamieson AM, Pasman L, Yu S et al. Role of tissue protection in lethal respiratory viral-bacterial coinfection. Science 2013; 340: 1230-4.

\section{Ny standard for EEG-beskrivelse}

\section{Norske leger og teknologer har vært sentrale i utviklingen av en ny standard for beskrivelse av EEG.}

Som ved de fleste medisinske prosedyrer beskrives resultatet av EEG-undersøkelser som oftest i fritekst, som lagres i pasientens journal. Dette gir rom for stor variasjon mellom ulike EEG-tolkere. Resultatene blir ikke søkbare og ikke tilgjengelige for statistiske analyser. Vår målsetting var å lage et dataprogram for EEG-tolking hvor man skulle benytte internasjonalt anerkjent terminologi og samtidig lagre funnene i en søkbar database. EEG-eksperter fra 14 europeiske land har deltatt $i$ utarbeidingen av terminologien og testing av programvaren, som har resultert $i$ et nytt skåringssystem kalt SCORE (Standardized Computer-based Organized Reporting of EEG). Arbeidet har vært organisert med støtte fra det europeiske avsnittet av organisasjonene International League Against Epilepsy (ILAE) og International Federation of Clinical Neurophysiology (IFCN), og resultatet er nylig publisert i tidsskriftet Epilepsia (1).

De norske nevrofysiologene Harald Aurlien og Jan Brøgger har sammen med teknologer i Holberg EEG AS ved Haukeland universitetssykehus utviklet SCORE-programvaren, som allerede er oversatt til flere språk.
Den lagrede informasjonen i databasen er imidlertid uavhengig av hvilket språk som brukes for beskrivelse. Dette betyr at resultater av EEG-undersøkelser nå kan sammenliknes direkte på tvers av ulike språk og tradisjoner. En gratis versjon av programvaren kan lastes ned fra www.holbergeeg.com/.

\section{Harald Aurlien}

harald.aurlien@helse-bergen.no

Nevrologisk avdeling

Haukeland universitetssykehus

Litteratur

1. Beniczky S, Aurlien H, Brøgger JC et al. Standardized Computer-based Organized Reporting of EEG SCORE. Epilepsia 2013; 54: 1112-24. 